\title{
Geochemical Color Maps of the Dhaka Water, Bangladesh-New Map Presentations for Toxic Metals and Isotopes
}

\author{
Mst Shamsun Nahar ${ }^{1}$, Md. Nurunnabi Mondal'2, Mohammad Ferdous Hasan ${ }^{3}$, Jannatun Shahin ${ }^{4}$, \\ Md. Ariful Haque ${ }^{5}$, Atsushi Nishii ${ }^{1}$
}

\author{
${ }^{1}$ Department of Environmental Analysis, Earth Consultant Co. Ltd., Toyama, Japan \\ ${ }^{2}$ Department of Fisheries Management, Faculty of Fisheries, Bangabandhu Sheikh Mujibur Rahman Agricultural University, \\ Gazipur, Bangladesh \\ ${ }^{3}$ Department of Computer Science and Engineering, Tokyo University of Technology, Tokyo, Japan \\ ${ }^{4}$ Department of Fisheries, Ministry of Fisheries and Livestock, Dhaka, Bangladesh \\ ${ }^{5}$ Department of Oceanography, University of Dhaka, Dhaka, Bangladesh \\ Email: *msnahar@yahoo.com, ${ }^{*}$ msnahar@e-consul.co.jp
}

How to cite this paper: Nahar, M.S., Mondal, M.N., Hasan, M.F., Shahin, J., Haque, M.A. and Nishii, A. (2017) Geochemical Color Maps of the Dhaka Water, Bangladesh-New Map Presentations for Toxic Metals and Isotopes. Journal of Geoscience and Environment Protection, 5, 134-151. https://doi.org/10.4236/gep.2017.53010

Received: December 6, 2016

Accepted: March 26, 2017

Published: March 29, 2017

Copyright $\odot 2017$ by authors and Scientific Research Publishing Inc. This work is licensed under the Creative Commons Attribution International License (CC BY 4.0).

http://creativecommons.org/licenses/by/4.0/

\begin{abstract}
This research investigated the water qualities and distribution of heavy metals concentration in rain, river, ground and supply waters, providing a baseline in Dhaka Urban, Bangladesh, against which future changes can be assessed. The water sample was collected in the Dhaka central zone, from a site located in the center of the Bengal Delta plain between $23^{\circ} 40^{\prime} \mathrm{N}-23^{\circ} 54^{\prime} \mathrm{N}$ latitude and $90^{\circ} 20^{\prime} \mathrm{E}-90^{\circ} 31^{\prime} \mathrm{E}$ longitude which is affected by environmental pollution for high traffic, industrialization and because of its rapid urbanization. The water samples were analyzed for heavy metals by Inductively Coupled Plasma MassSpectrometry (ICP-MS), major ions by Ion-Chromatography (IC), water tracer $\left(\delta^{8} \mathrm{O}\right.$ and $\left.\delta \mathrm{D}\right)$ by Mass-Spectrometry (MS), following the standard techniques. Elevated EC and chloride $\left(\mathrm{Cl}^{-}\right)$are the markers of wastewater, providing an indication of impacts in the Buriganga River water. The relative concentrations of major ions were presented in the form of Piper and Stiff Diagram. The color maps were constructed to present ions distribution over the areas. The stream reaches directly in Buriganga River from leather industries which may reflect the naturally low dissolved oxygen (DO) $0.3-3.5$ $(\mathrm{mg} / \mathrm{L})$, where aquatic life can't survive. Uranium contents $\mathrm{U}^{238}(0.1-2.7$ $\mu \mathrm{g} / \mathrm{L})$ are not exceeding the WHO guideline level of $30 \mu \mathrm{g} \cdot \mathrm{L}^{-1}$. Significant portion of $\mathrm{Cs}^{133}(0.05-0.32 \mu \mathrm{g} / \mathrm{L})$, Se $(0.03-0.12 \mu \mathrm{g} / \mathrm{L}), \mathrm{B}(50-2986 \mu \mathrm{g} / \mathrm{L})$ and $\mathrm{Cr}$ $(0.55-18.59 \mu \mathrm{g} / \mathrm{L})$, could be increased in Buriganga River areas by the effect of local sources like leather industry. Zn $(10-1466 \mu \mathrm{g} / \mathrm{L})$ in the Dhaka Rain and $\mathrm{Pb}(4-6 \mu \mathrm{g} / \mathrm{L})$ in Dhaka Water occur mainly in industrial and the high
\end{abstract}


traffic areas, respectively. The isotopic $\left(\delta^{18} \mathrm{O} / \delta \mathrm{D}\right)$ distributions have been evaluated for understanding of contaminant sources in groundwater and wastewater recharge from Buriganga River to adjacent depleted groundwater system. The results indicate that the magnitude of pollution problem depends on the size of the area affected, rapid groundwater depletion, polluted river water recharge and the type of the pollutant involved and finally that makes the complex in Dhaka Geochemical pattern.

\section{Keywords}

Uranium-238, Dhaka Urban, $\delta^{18} \mathrm{O}$, Geochemistry, Buriganga River, Cesium

\section{Introduction}

In this study, isotopes and element concentrations in rain, river, groundwater and other physicochemical properties of the Dhaka Water, designated geochemical color maps covering the Dhaka Urban, Bangladesh. About 17 percent of the supply water used in the Dhaka in recent time comes from secondary source of river-water and $83 \%$ from groundwater $(\mathrm{GW})$ sources. GW recharge in the upper aquifer is much less compared to abstraction, causing groundwater mining. Furthermore, growth in the Dhaka's $\left(470 \mathrm{~km}^{2}\right)$ population from 15 million people in 2015 to an estimated 35.5 million by 2050

(http://www.dhakatribune.com/bangladesh/2016) will critically stress already limited water supplies by DWASA [1].

The alternate future water source is surface water. In Dhaka case, urbanization concentrates domestic pollution and it is known that toxic heavy metals in surface and groundwater are directly correlated to heavy metals loading fluxes from direct discharge of wastewater from industries and polluted rain sources [2] [3]. Hazaribagh is home to $95 \%$ of Bangladesh's leather tanneries, which every day dump 22,000 cubic liters of toxic waste into Buriganga River, the city's main river and water supply [4].

According to the previous investigation, one of the important surface water sources, Buriganga River water contains lowest dissolved oxygen (DO), high content of water contaminant, threatening the quality of groundwater [4] [5]. Therefore, the influence of anthropogenic factors is of particular importance in Dhaka Urban and the geochemistry is a nonpareil concept that is distinguished from general geochemistry by the complex infrastructure and intense human activities associated with industrialization, high traffic, the abstraction and rapid depletion of groundwater, low recharge for unplanned urbanization with world's fastest population (density $28,410 / \mathrm{km}^{2}$ ) growing mega city centers [6]. Therefore, water bodies are often affected by the activities of nearby populations and achieving a balance between their development, and the sustainability of the environment is complex [4] [7] [8]. Once this balance is disturbed, it is difficult to put right the damage. Examples of studies which tackle this problem in other parts of the world and many broad geochemical dispersion patterns for urban 
geochemistry have been delineated [9]-[14]. Additionally, pollutants derived from long-range transport and local emission in urban site impact significantly of heavy metal compositions in rainwater [15]. The study comprised the determination of trace and toxic metals concentrations in rainwater by using modern analytical method [16].

Surface and groundwater quality will become the principal limiting factor for sustainable development in many countries early in this century [17]. Over-exploitation of the aquifer has led to a progressive decline in Dhaka Water levels. The resulting cone of depression is thought likely to be causing the infiltration of polluted surface water. Stable isotopic techniques can be used to characterize the hydrogeology and water sources the aquifer beneath Dhaka. Environmental isotope $\left(\delta^{18} \mathrm{O}\right.$ versus $\left.\delta^{8} \mathrm{H}\right)$ distributions can approaches identify the polluted River Buriganga as the main threat to groundwater quality, indicating priorities for monitoring and aquifer protection.

This is the first time; we determined the presence of uranium and cesium in rain, river and groundwater in Dhaka Urban by using ICP-MS analyzer. U238 is the most common isotope of uranium found in nature and the head of the uranium decay series and the $238 \mathrm{U}$ final stage had been replaced with lead [18]. Uranium isotopes (U234, U235, U238) are radioactive and poses health hazard. In contrast, uranium-238 cannot sustain a chain reaction, but it can be converted to plutonium-239.

This paper delineated the geochemical patterns for both major and trace elements in Dhaka Water. We have, therefore, drawn new maps for major ions, $\delta^{18} \mathrm{O}$ versus $\delta^{8} \mathrm{H}$, toxic heavy metals and radioactive isotopes using computerized software techniques as Generic Mapping Tools (GMT), Ocean Data View (ODV) and find the current geochemical pattern. This type of map may be used to establish general baselines against which more specific natural geochemical variations and human-induced perturbations can be appraised.

\section{Study Area}

There were total 26 sample sites were subdivided into two groups to reflect contrast between ground and surface water chemistry (Figure 1(a) and Figure 1(b)). Stations 1 - 18, were located in central Dhaka, in Buriganga River and in river bank sites $(90.300 / 90.500 \mathrm{E}, 23.70 / 23.90 \mathrm{~N})$ were occupied on 1st November 2015 (Figure 1(a) and Figure 1(b)). Dhaka is surrounded by deep, pollutantrich river waters (Buriganga, Turag, Balu and Shitalakhya River). Water samples were collected for the analysis of dissolved oxygen (DO), heavy and radioactive metals, major ions and water tracer $\left(\delta \mathrm{D}\right.$ and $\left.\mathrm{O} \delta^{18}\right)$. From the total samples list, seven were from discharge Drain $(1,2,5)$ including Buriganga River water $(6,8$, 10, 12), [1: Barui Khali, Rayer Bazar, Hazaribagh, 3: Boshila, West Dhanmondi; 5: Metro Housing, West Dhanmondi; 6: Zauchar, Kamrangirchar; 8: Bou Bazar, Godaraghat, Shahid Nagar; 10: Babu Bazar Boat Terminal; 12: Shadarghat Boat Terminal]; Groundwaters have been collected from the deep and shallow gro- 


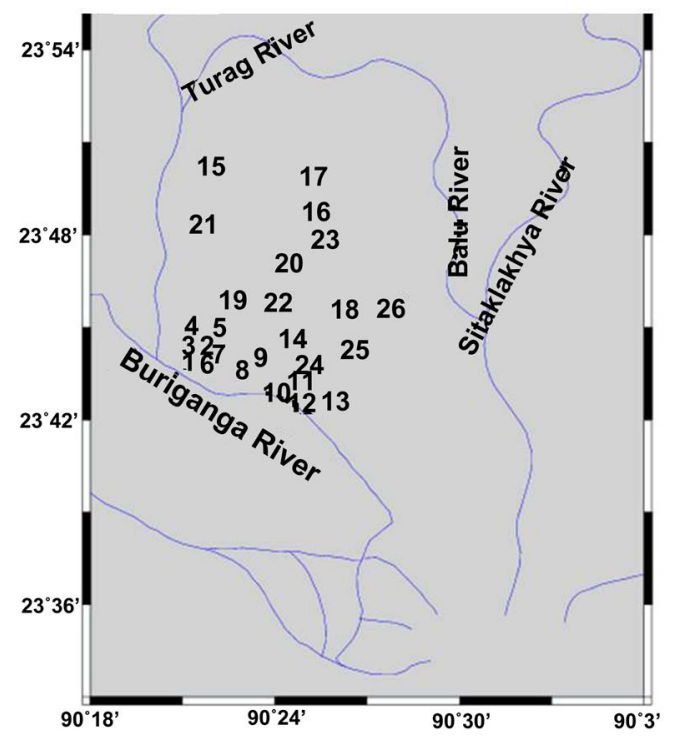

(a)

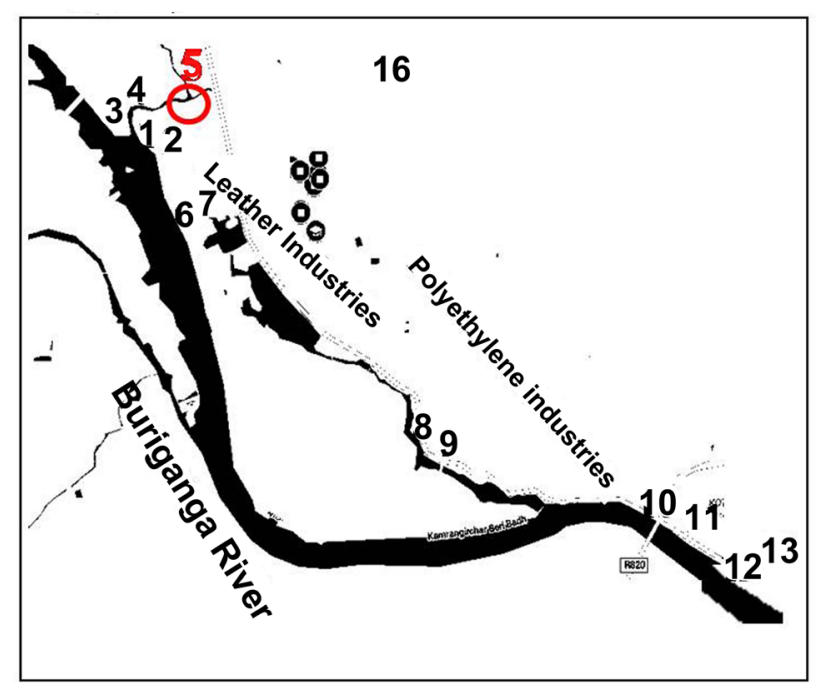

(b)

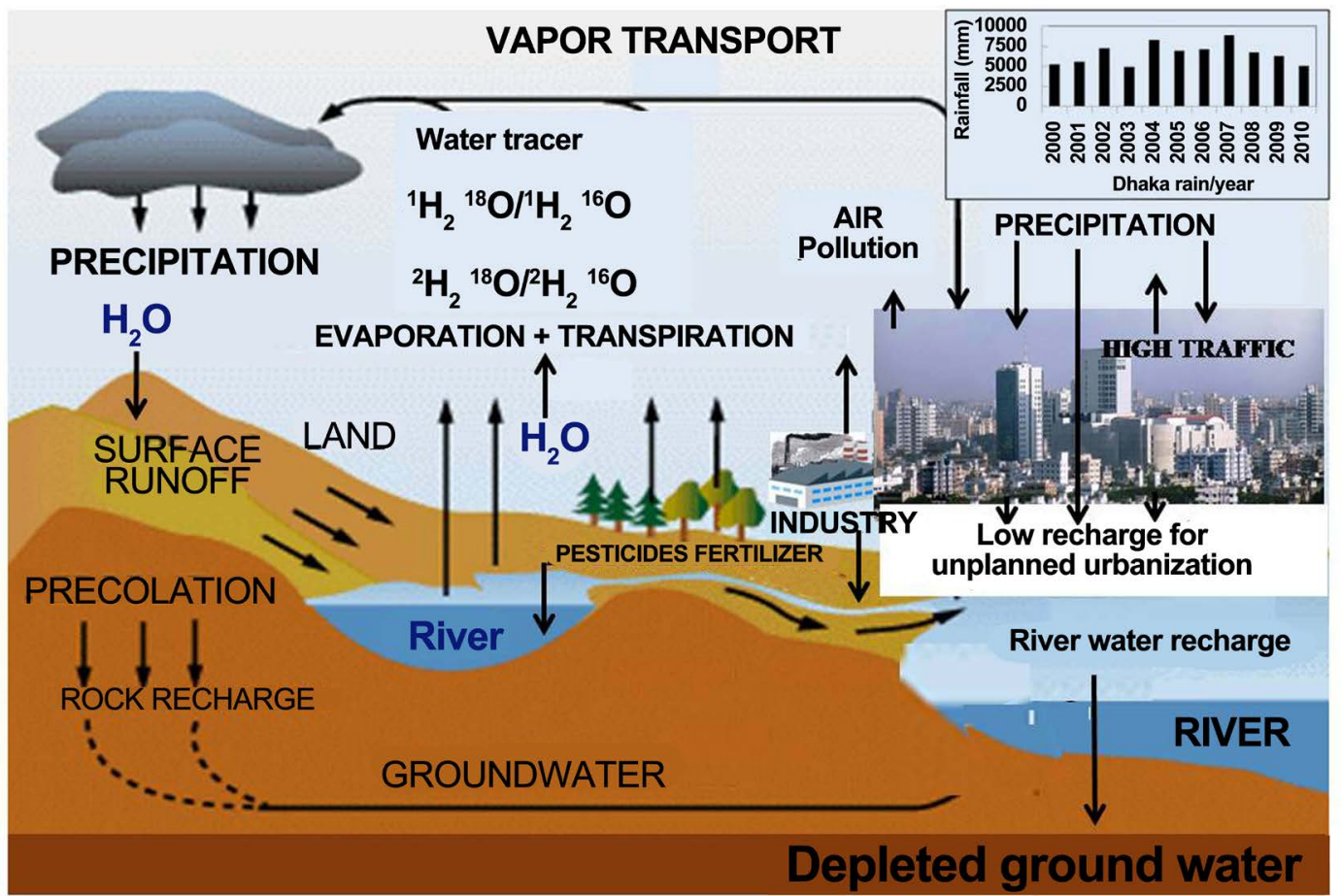

(c)

Figure 1. (a) Schematic diagram of study areas, rain, river, young ground, shallow ground and deep groundwater in Dhaka, Bangladesh. Discharge Drain $(1,2,5)$ and Buriganga Riverwater $(6,8,10,12)$ [1: BaruiKhali, Rayer Bazar, Hazaribagh, 3: Boshila, West Dhanmondi; 5: Metro Housing, West Dhanmondi; 6: Zauchar, Kamrangirchar; 8: Bou Bazar, Godaraghat, Shahid Nagar; 10: Babu Bazar Boat Terminal; 12: Shadarghat Boat Terminal]; groundwater: five deep groundwater (2, 4, 9. 11, 13), [2: BaruiKhali, Rayer Bazar, Hazaribagh; 4: Boshila; West Dhanmondi; 9: Bou Bazar, Godaraghat, Shahid Nagar; 11: Babu Bazar Boat Terminal; 13: Shadarghat Boat Terminal], one young groundwater [7: Zauchar, Kamrangirchar] and one shallow groundwater [16: Baribadh, Matikata, Dhaka] were adjacent to Buriganga River. Rainwater (14, 15, 17, 18) [14: Dhaka University; 15: Mirpur, Dhaka; 17: Baribadh, Matikata, Dhaka; 18: Railgate, Khilgaon, Dhaka]. Dhaka supply groundwater: Dhanmondi: 19, Tejgaon: 20, Mirpur: 21, Hazaribagh: 22, Banani: 23, Armanitola: 24, Motijheel: 25, Khilgaon: 26 (central Khilgaon, Balurpar, Gourlane, Nasirabad); (b) Sampling points of Buriganga River and groundwaters were close to the river bank. Sampling point 5 (discharge point): All untreated wastes of leather industries are flushed into the Buriganga River through the drain located in point 5; (c) Diagram of water recharge and water contamination process in Dhaka Urban. 
und water adjacent to the Buriganga River bank to investigate the river recharge as showing in Figure 1(a); five were collected from deep groundwater (2, 4, 9. 11, 13), [2: BaruiKhali, Rayer Bazar, Hazaribagh; 4: Boshila; West Dhanmondi; 9: Bou Bazar, Godaraghat, Shahid Nagar; 11: Babu Bazar Boat Terminal; 13: Shadarghat Boat Terminal], one was young groundwater [7: Zauchar, Kamrangirchar] and another one was from shallow groundwater [16: Baribadh, Matikata, Dhaka]. Rainwater $(14,15,17,18)$ were taken from high traffic, industrial and from new building construction areas [14: Dhaka University; 15: Mirpur, Dhaka; 17: Baribadh, Matikata, Dhaka; 18: Railgate, Khilgaon, Dhaka]; Dhaka supply groundwaters were taken from Dhanmondi: 19, Tejgaon: 20, Mirpur: 21, Hazaribagh: 22, Banani: 23, Armanitola: 24, Motijheel: 25 and Khilgaon: 26 (central Khilgaon, Balurpar, Gourlane, Nasirabad) areas. To clarify the water bodies, several symbols (R: river water, G: groundwater, Ra: rainwater) have been used with station numbers $(1,2,3,4,5,6,7,8,9,10,11,12,13,14,15,16,17,18)$ in some data set (e.g., for rainwater: Ra14, Ra15, Ra17, Ra18, Buriganga River water: R1, R3, R5, R6, R8, R10, R12, and groundwater: G2, G4, G7, G9. G11, G13, G16 etc.). Additionally, the Figure 1(b) also shows the main discharge point (R5) of industrial wastewater and the flow path to Buriganga River areas.

We also investigated the quality and hydrology of supply groundwater from seven central city of Dhaka district (Dhanmondi: 19, Tejgaon: 20, Mirpur: 21, Hazaribagh: 22, Banani: 23, Armania: 24, Motijheel: 25 and Khilgaon: 26 (water zone: center of Khilgaon, Balurpar, Gourlane, Nasirabad). Each sampling point is adjacent to site-specific pollution sources, dominated by industrialization (old Dhaka: Hazaribagh, new Dhaka: Tejgaon), new building construction (Matikata), high traffic (Motijheel, Mirpur, Khilgaon) and commercialization (Motijheel) (Figure 1(c)) in Dhaka Urban. Moreover, we also added some supply tap water sources for geochemical comparison, e.g. shallow groundwater (Saturia: far from central Dhaka), deep groundwater (Agamashi lane: old Dhaka) and groundwater (Mohammadpur).

\section{Experimental}

\subsection{Reagents and Materials}

All reagents used in this work were of analytical grade. Ultrahigh-purity nitric acid (El grade and Tamapure AA-100), and Wako Milli-Q2 (Tamapure AA-100, Ultrapur, Kanto Chemical) were used for all operations.

Reference water samples

The precision of the ICP-MS procedure and the accuracy for each run for each samples were evaluated using a spiked river water reference material (JSAC0302-3C) obtained from The Japan Society for Analytical Chemistry (JSAC).

\subsection{Major Ions Determination}

Major ions (Cations: $\mathrm{Na}, \mathrm{K}, \mathrm{Mg}, \mathrm{Ca}$ and anions: $\mathrm{Cl}, \mathrm{NO}_{3}$ and $\mathrm{SO}_{4}$ ) were determined by DIONEX1 (DX-120)-compact ion chromatography. The Charge-Bal- 
ance Error $(\mathrm{CBE})$ values was within limit $(< \pm 5 \%-10 \%)$. Alkalinity was measured on filtered groundwater samples.

\subsection{Trace Metals Detection by Using ICP-MS (Agilent 7700)}

Inductively Coupled Plasma Mass Spectrometer (ICP-MS, Agilent 7700. Earth Consultant Co. Ltd., Japan) procedures were performed using a $1 \mathrm{M}$ HNO3 (TAMAPURE AA-100) eluent containing extremely low levels of trace metals. ICP-MS standard solutions of selected elements were purchased from USA (SPEX Certi Prep, 1000 mg L-1, Cr, As, Se, B, Cd, Pb, Cu, Zn, U, Cs, Fe, Mn etc.) [16]. $1000 \mathrm{mg} / \mathrm{L}$ solution of Be, Y, Rh, Ga, In and Bi (WAKO Pure Chemical Industries Ltd.) was used as an internal standard for normalization of individual isotopic intensities (cps) to correct for variations in instrument sensitivity over the course of the experiment, and all calculations in this study employed the corrected values. The machine was equipped with nickel skimmer cones (Spectron), but the Ni background associated with the cones was not significant relative to the Ni signal of the samples and employ a collision/reaction cell (CRC) to reduce the interferences of sample matrix. The low-resolution MS mode was used for isotope measurements. Samples were pumped into the instrument at 50 $\mu \mathrm{L} \cdot \min ^{-1}$.

\subsection{Water Tracer ( $\delta \mathrm{D}$ and $\left.\delta^{18} 0\right)$ Measurement}

The hydrogen and oxygen isotope ratios of all samples were measured using a mass spectrometer (Micromass model PRISM) housed at the University of Toyama, Japan [19]. Samples were prepared using the $\mathrm{H}_{2} \mathrm{O}-\mathrm{H}_{2}$ equilibrium method with a hydrophobic platinum catalyst for $\delta \mathrm{D}$ and the $\mathrm{H}_{2} \mathrm{O}-\mathrm{CO}_{2}$ equilibrium method for $\delta^{18} \mathrm{O}$. Isotope ratios are expressed as $\delta$-values, which are represented by the following Equation (Eq.1), in \%o unit relative to V-SMOW

$$
d(\%)=\left(\text { Rsample } / R V \_S M O W-1\right) \times 1000
$$

R: D/H or $18 \mathrm{O} / 16 \mathrm{O}$

Eq.1

The obtained accuracy is better than $\pm 1.5 \%$ o for $\delta \mathrm{D}$ and $\pm 0.1 \%$ o for $\delta^{18} \mathrm{O}$.

\section{Results and Discussions}

Dhaka Rivers are primarily fed by local rainfall, wastewater and storm water along its course through many point sources such as sluice gates, city drains and effluent outfall of the Pagla Sewage Treatment Plant (PSTP) and also receive runoff from the considerably larger Ganges-Brahmaputra-Rivers (GBR) system. All groundwater is obtained locally from underlying fluviodeltaic sands of the highly productive DupiTila Aquifer, which is locally reported to be about $140 \mathrm{~m}$ thick. Intensive groundwater mining from the upper DupiTila Aquifer has significantly influenced the groundwater flow direction [20] [21]. Monitoring of the spatial and temporal distribution of groundwater levels (GWL) in Dhaka City has shown a significant decrease in GWL in the central and western regions since 1980 [20]. Regional groundwater flow was directed towards the south and 
southeast of the city.

\subsection{Geochemical and Graphical Plot for Major Ions (Piper and Stiff Diagram)}

\subsubsection{Stiff Diagram of Major Ions in Water Samples}

Stiff Diagram is useful in making a rapid visual comparison between water from different sources [22]. It displays the concentrations of three pairs of major anion-cation constituents in rain (Ra: 14, 15, 17 and 18), river $(1,3,5,6,8,10$, 12), shallow-ground (station G16, Saturia), young groundwater (station G7, Mirpur, Tejgoan, Banani) deep-groundwater (G: 2, 4, 9, 11, 13, Dhanmondi, Hazaribagh) and tap water (24: Armanitola, 25: Motijheel, 26: (Khilgaon, Gourlane, Balurpar, Nasirabad), Agamashi), plotted in units of mEqL-1 (Figure 2). Figure 2 helps to visualize the ionic composition of a water body changes (rain < river $<$ shallow groundwater $<$ young groundwater $<$ deep groundwater) over space and/or time. The horizontal bar lengths represent ionic concentrations but the vertical separations of the bars and the line segments that link the bars have no physical meaning. The size of the diagram reflects the total ionic concentration. Figure 2 shows the Stiff Diagram for the Dhaka Water samples [22] [23]. The concentration of the major ions in the water samples were converted from the measured units of $\mathrm{mg} \cdot \mathrm{L}^{-1}$ into molar concentrations accounting for ionic charge. The Stiff Diagram shows not only the range of major ion compositions for the Dhaka Water samples, but also shows the difference of minerals in rain, river, shallow ground, deep ground and tap water types, sampled from stations 1 to 26. All diagrams are consistent with the $\mathrm{Ca}-\mathrm{HCO}_{3}$ and $\mathrm{Na}-\mathrm{Ca}-\mathrm{HCO}_{3}$ water type. Deep groundwater samples from Hazaribagh (stations 2, 4, 7, 9, 11, 13) and Old Dhaka (Agamashi Lane) areas, exhibited higher sodium and calcium concentrations $\left(20-85 \mathrm{mgL}^{-1}\right)$ than the other stations Motijheel, Dhanmondi (11 $50 \mathrm{mg} / \mathrm{L}$ ). Na-Ca- $\mathrm{HCO}_{3}^{-}$(stations 2, 4, 7, 9, 11, 13, Agamashi, Hazaribagh) water may form during silicate hydrolysis when longer residence times result in the dissolution of Na-feldspar or from the exchange of $\mathrm{Ca}$ for $\mathrm{Na}$ during evolution of groundwater along a flow path [8]. Na-Ca- $\mathrm{HCO}_{3}$-type water contains higher $\mathrm{SiO}_{2}$ and $\mathrm{Na}$ concentrations (Figure 2 and Table 1). Dissolved $\mathrm{K}^{+}$appears in groundwater as a result of silicate weathering (Table 1). River water from Buriganga, such as station 1, 3, 5, 6, 8, 10 and 12, contain higher $\mathrm{Na}$ (154.1 - 440.2 $\mathrm{mg} / \mathrm{L}$ ) but low $\mathrm{SiO}_{2}$ values, indicating different source for $\mathrm{Na}^{+}$and $\mathrm{Cl}^{-}$ions. Elevated EC $(375.5 \mathrm{mg} / \mathrm{L})$ and chloride $(39.97 \mathrm{mg} / \mathrm{L})$ in main discharge point 5 and station 8 are the marker of wastewater, provided an indication of impacts in the Buriganga Water (Figure 2 and Table 1). The water from G16 and Saturia (shallow depth wells) had narrower shaped diagrams than G9, G11 or G13 (deep ground) water, indicating low ionic concentrations due to short contact time of the water with the bedrock [8]. The Stiff Diagram for young groundwater (G7) shows a Ca- $\mathrm{HCO}_{3}^{-}$water type with a higher $\mathrm{Ca}^{++}$and lower $\mathrm{Na}^{+}$composition. Rainwater contained low minerals and the EC are $18-50 \mu \mathrm{S} / \mathrm{cm}^{2}$, however the anion concentration $\left(\mathrm{HCO}_{3}^{-}, \mathrm{SO}_{4}^{2-}\right.$ and $\left.\mathrm{NO}_{3}^{-}\right)$were little higher $(5-10$ 


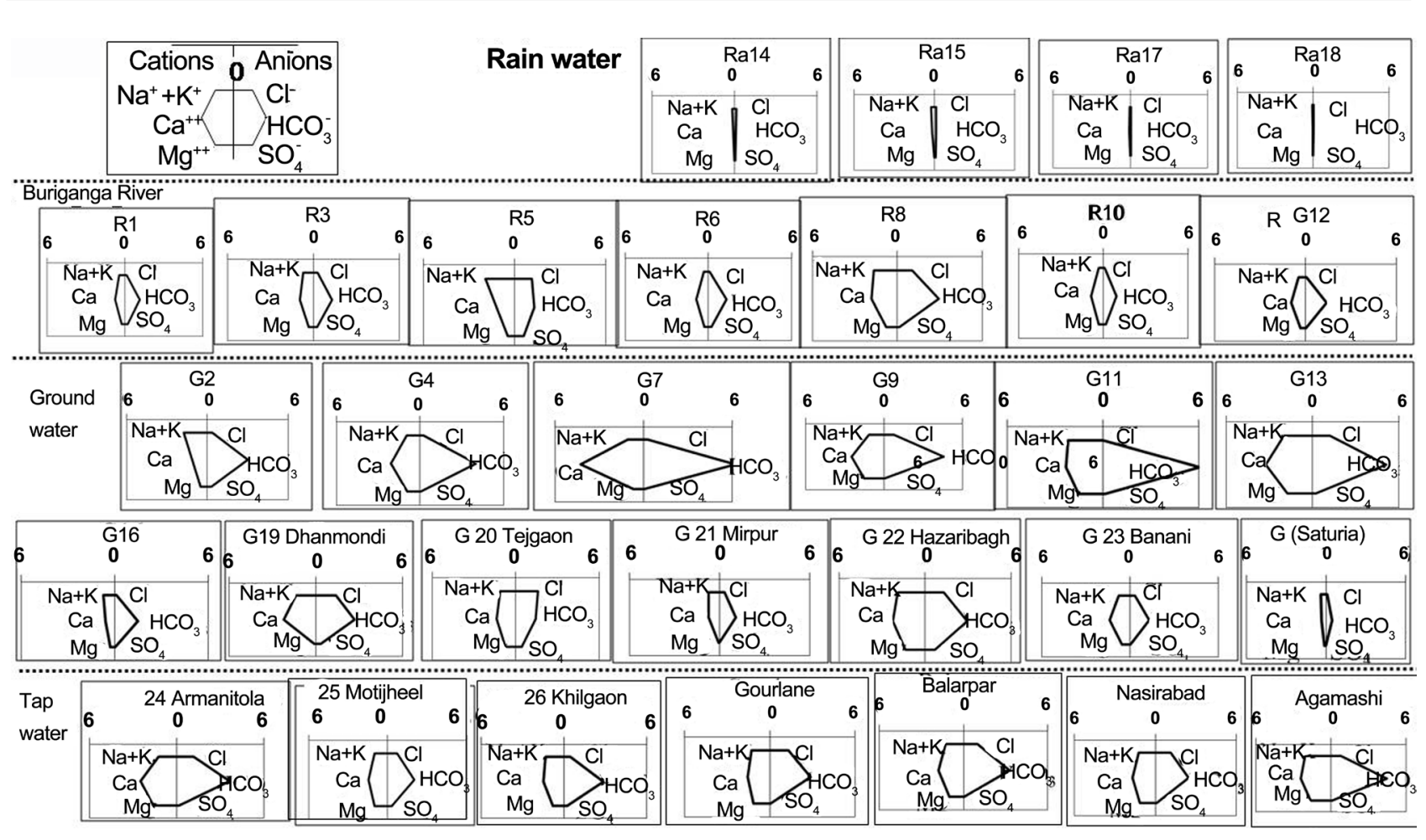

Figure 2. Graphical presentation and classification for assessment of water quality by using Stiff Diagram. Legend; R: river water, G: groundwater, Ra: rainwater. Rainwater (Ra14, Ra15, Ra17, Ra18), Buriganga River water: R6, R8, R10, R12, Discharge point (R5, R3, R1), Groundwater: Six deep groundwater, G2 (140 m), G4 (250 m), G9 (250 m), G11 (250 m), G13; G16; one young groundwater G7, adjacent to Buriganga River; Dhaka supply groundwater: Dhanmondi: G19 (42 m), Tejgaon: G20 (67 m), Mirpur: G21 (57 m), Hazaribagh: G22 (69 m), Banani: G23 (63 m), Saturia: shallow groundwater (10 m). Tap water Armanitola: 24, Motijheel: 25, Khilgaon: 26 (Khilgaon center, Balurpar, Gourlane, Nasirabad). Agamashi.

Table 1. Physical and chemical property of rain, river and groundwater in Dhaka Urban (mg/L). Legend; R: river water (R1, R3, R5, R6, R8, R10 and R12), G: groundwater (G2, G4, G7, G9, G11, G13 and G16) and Ra: rainwater (Ra14, Ra15, G16, Ra17 and Ra18).

\begin{tabular}{|c|c|c|c|c|c|c|c|c|c|c|c|c|c|c|c|c|c|c|}
\hline Station & Date & $\begin{array}{l}\text { Lon } \\
(-E)\end{array}$ & $\begin{array}{l}\text { Lat } \\
(-\mathrm{N})\end{array}$ & EC & TDS & DO & $\mathrm{pH}$ & ${ }^{\circ} \mathrm{C}$ & $\mathrm{SiO}_{2}$ & $\mathrm{Na}^{+}$ & $\mathrm{K}^{+}$ & $\mathrm{Ca}^{++}$ & $\mathrm{Mg}^{++}$ & $\mathrm{HCO}_{3}^{-}$ & $\mathrm{Cl}^{-}$ & $\mathrm{NO}_{3}^{-}$ & $\mathrm{SO}_{4}^{-}$ & $\begin{array}{c}\text { Ion } \\
\text { balance }\end{array}$ \\
\hline $\mathrm{R} 1$ & $9 / 1 / 2$ & 90.3522 & 23.7407 & 159.4 & 102.0 & 3.1 & 6.8 & 28.7 & 7.20 & 56 & 2.70 & 15.33 & 3.10 & 0.03 & 5.13 & 40 & .74 & -5.10 \\
\hline G2 & $9 / 1 / 2015$ & 90.3533 & 23.7412 & 357.7 & 228.9 & 7.3 & 7.2 & 27.3 & 24.36 & 38.20 & 4.25 & 22.35 & 6.00 & 185.01 & 13.98 & 3.13 & 14.14 & -5.57 \\
\hline R3 & $9 / 1 / 2015$ & 90.3511 & 23.7416 & 221.4 & 141.7 & 0.7 & 6.4 & 28.6 & 8.59 & 13.23 & 5.58 & 18.74 & 4.11 & 79.43 & 10.88 & 16.25 & 12.92 & -3.69 \\
\hline G4 & $9 / 1 / 2015$ & 90.3509 & 23.7417 & 400.5 & 256.3 & 2.7 & 6.5 & 28.2 & 25.36 & 20.22 & 2.47 & 41.71 & 11.11 & 245.40 & 9.18 & 2.02 & 3.12 & -5.43 \\
\hline R5 & $9 / 1 / 2015$ & 90.3566 & 23.7441 & 375.5 & 240.3 & 0.3 & 6.6 & 28.5 & 7.92 & 41.08 & 4.87 & 23.89 & 5.39 & 78.12 & 39.97 & 9.58 & 28.59 & 5.76 \\
\hline R6 & $9 / 1 / 2015$ & 90.3563 & 23.7337 & 160.9 & 103.0 & 4.2 & 6.9 & 28.7 & 6.37 & 5.98 & 3.10 & 17.94 & 3.68 & 80.54 & 2.66 & 3.76 & 9.23 & -3.60 \\
\hline G7 & $9 / 1 / 2015$ & 90.3565 & 23.7331 & 611.1 & 391.1 & 2.5 & 6.3 & 27.8 & 13.74 & 21.81 & 4.29 & 85.24 & 8.15 & 378.89 & 10.50 & 6.44 & 2.21 & -5.47 \\
\hline $\mathrm{R} 8$ & $9 / 1 / 2015$ & 90.3790 & 23.7162 & 440.2 & 281.7 & 0.5 & 6.1 & 28.8 & 15.25 & 32.72 & 8.98 & 36.49 & 9.63 & 180.09 & 36.88 & 3.92 & 6.68 & 0.75 \\
\hline G9 & $9 / 1 / 2015$ & 90.3799 & 23.7164 & 522.9 & 334.7 & 3.4 & 6.0 & 27.6 & 34.79 & 25.69 & 2.19 & 50.05 & 18.16 & 280.52 & 27.71 & 1.07 & 2.54 & -2.80 \\
\hline R10 & $9 / 1 / 2015$ & 90.4019 & 23.7097 & 154.1 & 98.6 & 4.2 & 6.8 & 28.6 & 4.56 & 5.74 & 3.02 & 17.93 & 3.78 & 55.99 & 2.73 & 13.73 & 8.88 & 4.35 \\
\hline G11 & $9 / 1 / 2015$ & 90.4022 & 23.7099 & 583.8 & 373.6 & 1.5 & 6.0 & 27.6 & 36.83 & 48.88 & 2.53 & 45.80 & 18.49 & 372.10 & 2.02 & 3.99 & 6.97 & -3.10 \\
\hline R12 & $9 / 1 / 2015$ & 90.4086 & 23.7060 & 159.9 & 102.3 & 3.0 & 6.8 & 28.5 & 5.09 & 8.32 & 3.37 & 18.40 & 3.92 & 85.94 & 3.00 & 1.90 & 2.07 & 3.62 \\
\hline G13 & $9 / 1 / 2015$ & 90.4096 & 23.7059 & 689.6 & 441.3 & 4.8 & 6.4 & 28.8 & 26.00 & 42.07 & 7.27 & 65.14 & 21.54 & 312.60 & 43.74 & 3.05 & 9.56 & 3.06 \\
\hline Ra14 & $9 / 1 / 2015$ & 90.4008 & 23.7266 & 38.3 & 24.5 & 7.4 & 7.3 & 28.2 & 0.58 & 1.79 & 4.32 & 2.22 & 0.13 & 6.51 & 4.17 & 2.79 & 2.23 & -0.92 \\
\hline Ra15 & $9 / 1 / 2015$ & 90.3637 & 23.8345 & 54.7 & 35.0 & 6.6 & 6.8 & 27.0 & 1.27 & 2.14 & 5.97 & 3.51 & 0.25 & 9.11 & 4.59 & 5.24 & 4.37 & -1.54 \\
\hline G16 & $9 / 1 / 2015$ & 90.3954 & 23.8202 & 161.1 & 103.1 & 6.9 & 6.8 & 31.7 & 28.33 & 14.48 & 2.99 & 11.75 & 3.47 & 90.47 & 4.72 & 3.89 & 1.17 & -3.91 \\
\hline Ra17 & $9 / 1 / 2015$ & 90.3954 & 23.8202 & 23.6 & 15.1 & 8.0 & 7.4 & 25.7 & 0.32 & 0.75 & 1.22 & 2.20 & 0.32 & 2.60 & 1.41 & 4.50 & 1.80 & 1.81 \\
\hline Ra18 & $9 / 1 / 2015$ & 90.4230 & 23.7465 & 18.6 & 11.9 & 8.1 & 8.3 & 27.3 & 1.34 & 0.82 & 1.22 & 1.10 & 0.49 & 3.26 & 0.90 & 3.60 & 0.98 & 1.44 \\
\hline
\end{tabular}


$\mathrm{mg} / \mathrm{L}$ ) in high traffic density roads (Mirpur) and commercial areas.

\subsubsection{Piper Diagram for Rock Determination in Water Samples}

A Piper plot is a way of visualizing the chemistry of a rock, soil, or water sample. Piper Diagrams graphically represent some of the multiple variables associated with major cation and anion data and aid in rapid determinations of rock types as well as similarities and differences in water samples [24]. The results of the process is then plotted as a trilinear diagram, as shown in Figure 3(a), where each axis varies from $0 \%-100 \%$ in abundance. Figure $3(\mathrm{a})$ also shows the anion $\left(\mathrm{HCO}_{3}^{-}, \mathrm{SO}_{4}^{2-}\right.$ and $\left.\mathrm{Cl}^{-}\right)$and cation $\left(\mathrm{Na}^{+}, \mathrm{K}^{+}, \mathrm{Ca}^{2+}\right.$ and $\left.\mathrm{Mg}^{2+}\right)$ facies in the form of major-ion percentages and the majority of the 26 water samples. The diagram for the cation facies in Figure 3(a) shows that the majorities of the samples are dominated by $\mathrm{Ca}$ and are thus Ca-type water. Figure $3(\mathrm{~b})$ shows the variation of ionic composition of a set of water samples for different water bodies (rain, river and groundwater). The diagram for the anion facies in Figure 3(a) shows the anion predominance in the samples and indicates that the majority (98\%) of the samples lie in the range of $\mathrm{HCO}_{3}>50 \%$ and can thus be considered $\mathrm{HCO}_{3}$-type water. The sequences $\mathrm{Ca}^{2+}>\mathrm{Mg}^{2+}>\mathrm{Na}^{+}$and $\mathrm{HCO}_{3}^{-}>\mathrm{SO}_{4}^{2-}>\mathrm{Cl}^{-}$are characteristic of relatively freshwater with a short residence time, which is indicative of shallow groundwater as reported previously for the present study area [8]. $\mathrm{Ca}^{-}$ $\mathrm{Mg}^{-}$type water predominated in the samples based on our analysis. Ninety percent $(90 \%)$ of the samples were categorized as $\mathrm{Ca}-\mathrm{Mg}$ type. There are six main water supply zones in Dhaka City (Figure 3(c)); Zones 1 (leather industrial areas), Zones 1 and 2 are in the older more densely populated southern part of the city, Zone 4, 5 are the high traffic area, Zone 6 coincides with the major industrial district of Tejgaon located north of the old city center. Zones 1, 2 and 6 have seen the most intensive well development, but during the 1990s new drilling has increasingly extended to the other supply zones. Abundances of major ions and low dissolved oxygen (DO) $0.3-3.0 \mathrm{mg} / \mathrm{L}$ (Table 1) were found in $\mathrm{Bu}-$ riganga River water adjacent to industrial areas.

Color mapping was constructed to illustrate the relative abundances of the major anions $\left(\mathrm{HO}_{3}^{-}, \mathrm{SO}_{4}^{2-}, \mathrm{HCO}_{3}^{-}\right.$and $\left.\mathrm{Cl}^{-}\right)$and cations $\left(\mathrm{Na}^{+}, \mathrm{K}^{+}, \mathrm{Ca}^{2+}\right.$ and $\mathrm{Mg}^{2+}$ ) in water from different stations (Figure 3(d)). Most of the water samples tested lie in the range of $\mathrm{HCO}_{3}^{-}$and can thus be considered as bicarbonate type water (Figure $3(\mathrm{e})$ ). The color mapped data shows the variation between water from different sources and indicates the high concentration of major ions were found in water from industrial areas, especially Hazaribagh, as compared to water from another city (Bonani city) (Figure 3(d) and Table 1). The water from Buriganga River, Hazaribagh (stations: 1 - 13) and Tejgaon city (station: 20) had higher concentrations of minerals than other stations. The elevated minerals concentrations may be due to pollution of the discharge water from the industry (Figure 1(b) and Table 1). The color mapped data also shows the elevated cation and anion concentrations in the water samples obtained from stations in deep groundwater (stations, 2, 4, 9, 11, 13) as compared to young groundwater (station 7) and shallow groundwater (station 16) (Figure 2 and Figure 3(d)). 


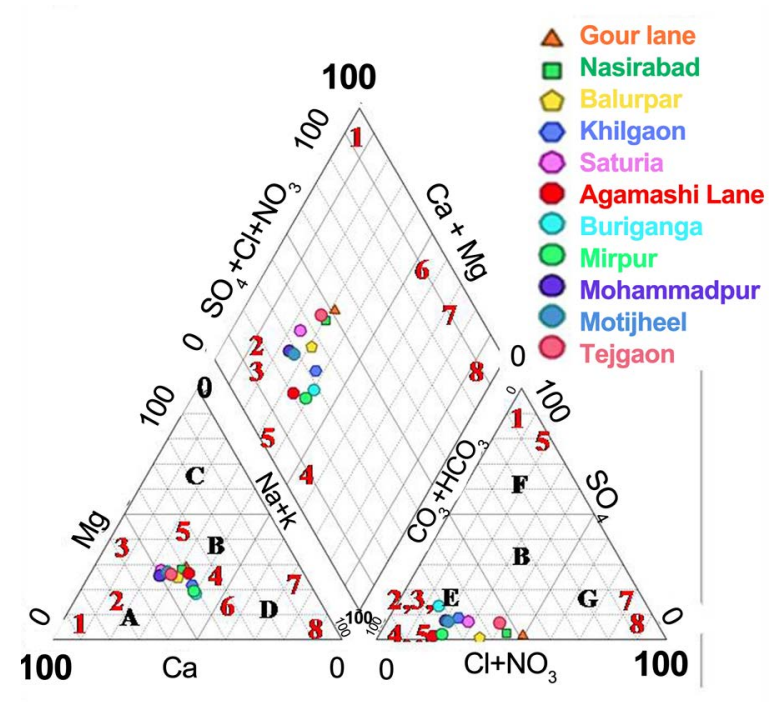

(a)

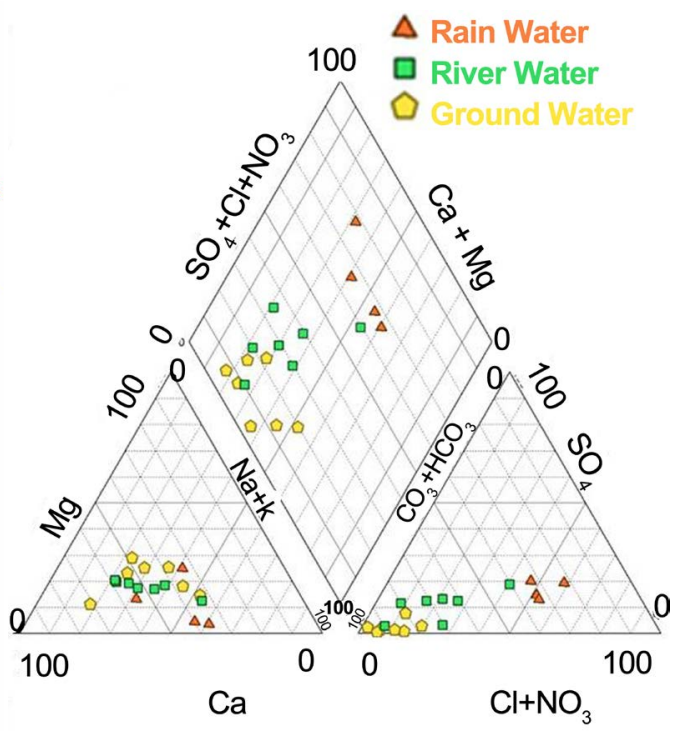

(b)

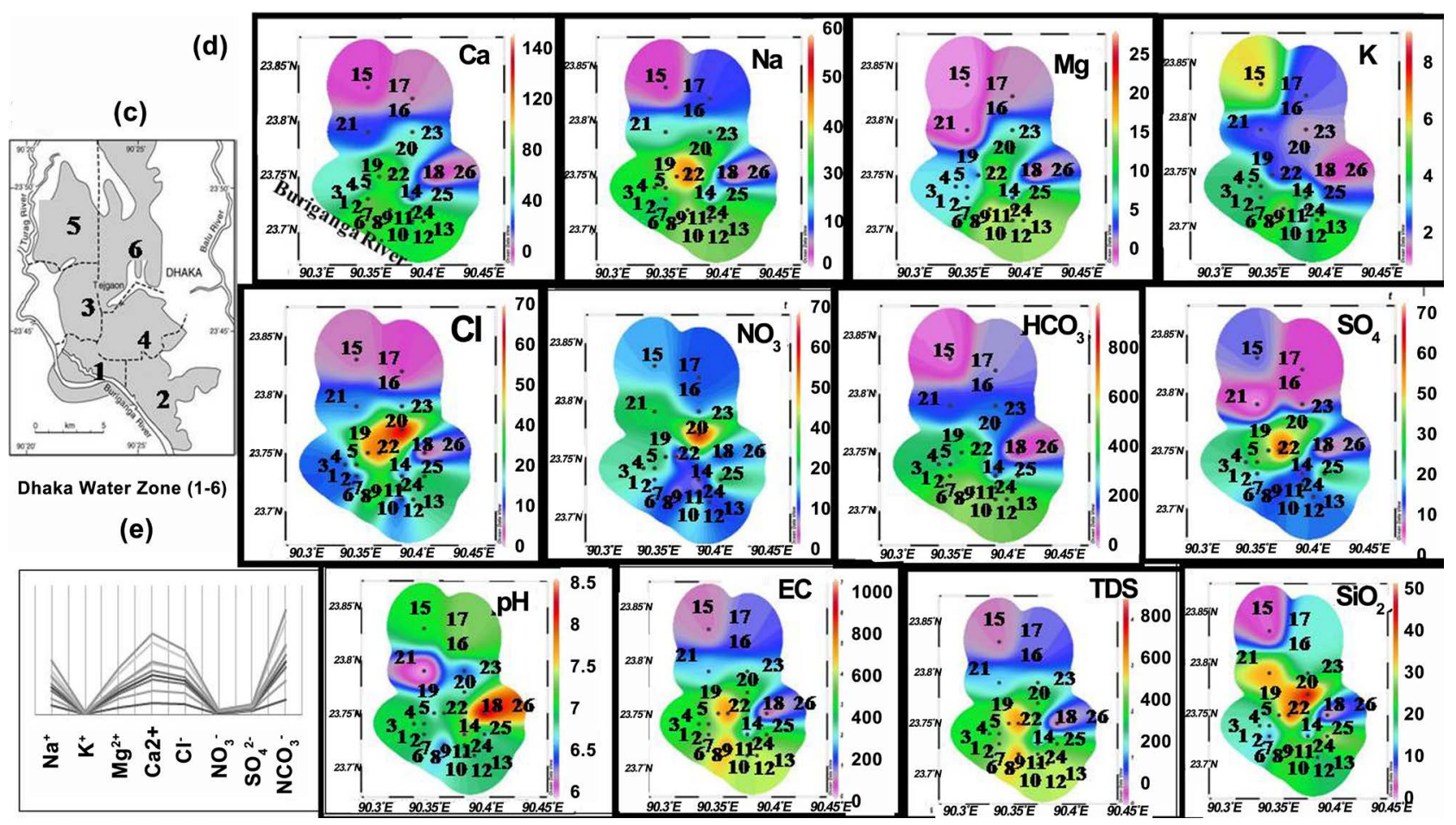

Figure 3. (a) Piper trilinear diagram of major ion and geochemical results for Dhaka tap water. Legend 1: Rock types are designed according to the domain in which they occur on the diagram segments. gypsum (1), calcite (2), dolomite (3), rhyolite (4), basalt (5), shale (6), seawater: 7, brine: 8. Legend 2: Classification diagram for anion and cation facies in the form of major-ion percentages; A-calcium type, B-no dominant type, C-magnesium type, D-sodium and potassium type, E-bicarbonate type, F-sulphate type, G-chloride type; (b) Compare the variation of ionic composition for different water bodies (rain, river and groundwater); (c) Water Levels Dhaka is zoned for water-supply purposes into six districts, with newer zones having the higher numbers; (d) Colored surface map of major ions distribution in rain, river, ground and tap water of the Dhaka Urban (unit: mg/L); (e) Dhaka Water are dominated by bicarbonate $\left(\mathrm{Ca}-\mathrm{HCO}_{3}\right.$ and $\mathrm{Ca}-\mathrm{Na}-\mathrm{Mg}-\mathrm{HCO}_{3}-\mathrm{Cl}$ type).

In this study, four precipitation samples (Ra: 14, 15, 17, and 18) were collected at three sampling sites near high traffic area (Ra: 15, 18), high way and new 
building construction site (Ra: 17) and Buriganga River site (Ra: 14) (Table 1). $\mathrm{NO}_{3}$ was higher in rainwater.

$\mathrm{HCO}_{3}$-type water predominated based on anion analysis (99\% of the samples), and the water was classified in one main group: bicarbonate (Figure 3(e)).

\subsection{Dissolved Oxygen (DO) in Buriganga River}

$\mathrm{DO}(\mathrm{mg} / \mathrm{L})$ is considered in the assessment of Buriganga River water resources (not for drinking water) for the purposes of their sustainability to aquatic life or in wastewater treatment studies (Table 1). The DO level within the $17 \mathrm{~km}$ reach of the Buriganga is alarmingly low, at some locations it even goes down to 0.1 $\mathrm{mg} / \mathrm{L}$ during the dry season [1]. The DO content in leather industrial discharge point is $0.3 \mathrm{mg} / \mathrm{L}$ (Table 1 : R5).

\subsection{Toxic Heavy Metals and Radioactive Isotopes in Dhaka Water}

Toxic metal levels in river and groundwater samples in Dhaka (Figure 4(a), Table 2) show that the concentrations of heavy metals are quite different. Toxic (B, $\mathrm{Se}, \mathrm{Cr}, \mathrm{Cu} \mathrm{As}, \mathrm{Pb}, \mathrm{Cd}, \mathrm{Mn}, \mathrm{Fe}$ ) and radioactive elements (U238 and Cs133) were measured by using ICP-MS. The concentrations of radioactive elements (U238 and Cs133) were higher in industrial sites (Figure 4(b)). Elevated concentrations of $\mathrm{Cr}, \mathrm{B}, \mathrm{Mn}$ and $\mathrm{Fe}$ in Buriganga River water are usually due to leather industries [25]. In this study, the concentrations of $\mathrm{Cr}, \mathrm{B}, \mathrm{Mn}$ and $\mathrm{Fe}$ in the river water samples were 0.4 - 18.59, 49.58 - 138.87, 5.3 - 23.84, and 12.97 - $83.71 \mu \mathrm{g} / \mathrm{L}$, respectively, whereas the concentrations of $\mathrm{Cr}, \mathrm{B}, \mathrm{Mn}$ and $\mathrm{Fe}$ in groundwater samples were $0.25-0.93,35.99-143.93,1.9-130.47,0.25-0.93$ (Table 2). The maximum contaminant level was evaluated with the standards limits for heavy metals in industrial wastewater, established by Japan Environmental Ministry are presented in Table 2 [26]. Concentration of arsenic (As) in Dhaka Water (ground and surface) shows minimum levels. Quantifying total arsenic (As) and As from interlocking geochemical cycles ( $\mathrm{Fe}, \mathrm{Mn}$ ) may assist in interpreting As dynamics in Dhaka well water [26]. Fe and Mn minerals efficiently scavenge As [27] [28]. However, Buriganga River and adjacent groundwater contained high content of $\mathrm{Cr}$ and $\mathrm{B}$ [29]. Because, during the chrome tanning process. $50 \%$ unused chromium salts are usually discharged in the final efluents, causing a serious threat to the Buriganga River [4]. From these features it can be inferred that high content of major ions, trace metals $(\mathrm{Cr})$ and other heavy metals are probably originate mainly from the wastewater and seem to be dumped to Buriganga River from leather industries. The highest level of heavy metals, boron (B), $\mathrm{Cl}, \mathrm{SO}_{4}, \mathrm{Na}$ and $\mathrm{EC}$ were detected in Buriganga River and groundwater near leather industrial areas, suggesting common source for these metals in that area (Table 1 and Table 2). The discharged waste from leather industries contain high chemical levels including salinity, organic load, ammonia, sulfide, chromium, chloride, sodium and other salt and heavy metals etc. [30]. Shallow groundwater (station 16) adjacent to industrial areas is highly polluted by $\mathrm{Zn}$, 


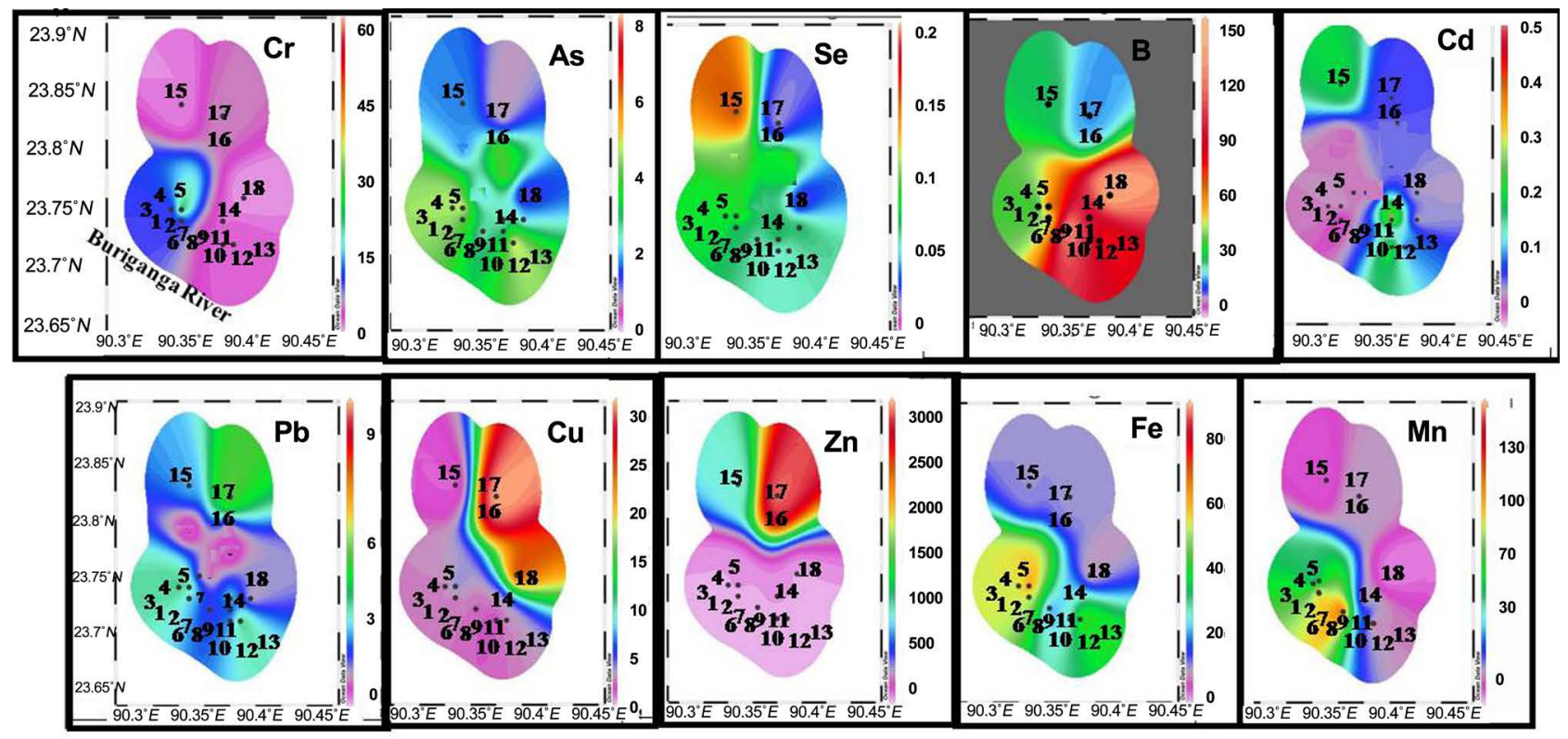

(a)

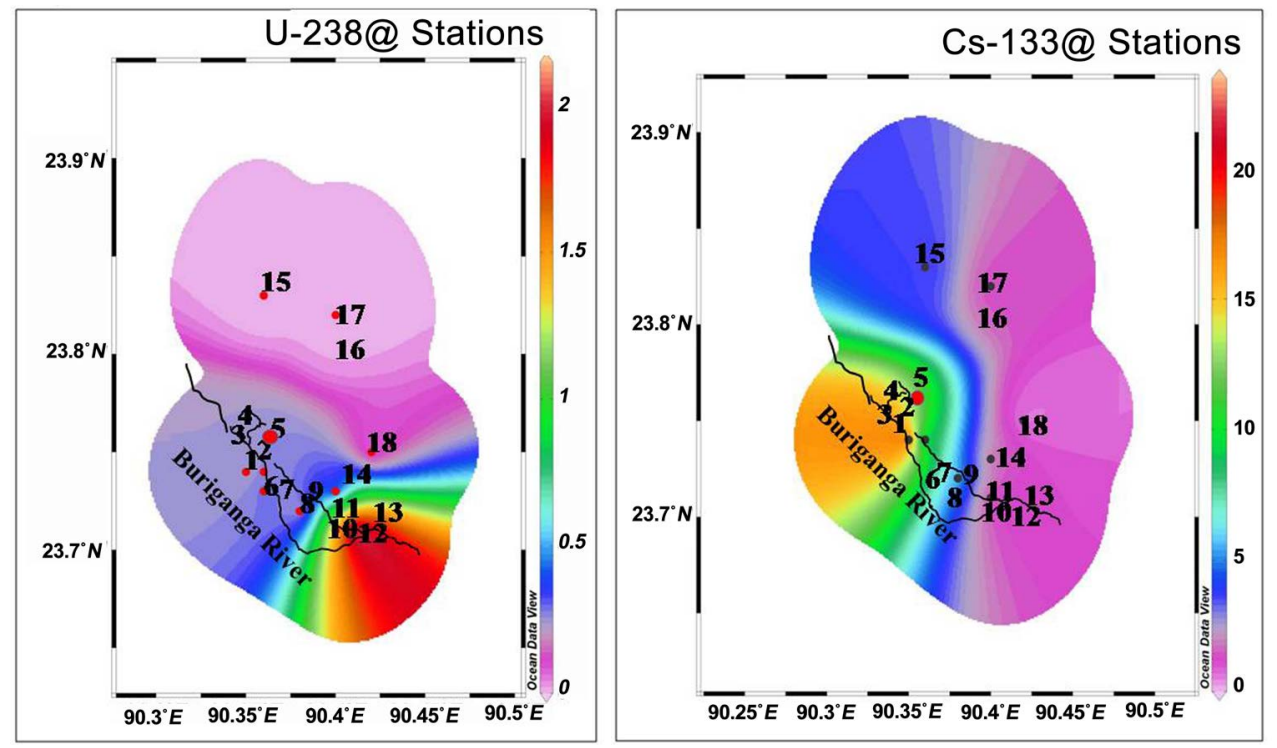

(b)

Figure 4. Colored surface map of heavy metals distribution in rain, river, ground and tap water of the Dhaka Urban (unit: $\mu \mathrm{g} / \mathrm{L}$ ). (a) Color map of toxic heavy metals; (b) Plot of radioactive metals in Buriganga River site (unit: $\mu \mathrm{g} / \mathrm{L}$ ).

$\mathrm{Cu}$ and $\mathrm{Pb}$. The study revealed that anthropogenic elements were highly enriched (especially $\mathrm{Zn}, \mathrm{Pb}, \mathrm{Cd}$ ) in rainwater (station $15,17,18$ ) [31]. Significant portion of $\mathrm{Zn}$ and $\mathrm{Pb}$, Se could be increased in air by the effect of local sources like vehicles, new building construction areas, respectively (Table 2). $\mathrm{Zn}$ and $\mathrm{Cu}$ concentration were very high in rain and groundwater at new building construction areas (St. 17, and 16). Pure metals or mixtures of metals such as $\mathrm{Cu}, \mathrm{Pb}$, and $\mathrm{Zn}$ are used in pipes, wiring, and roofing material and $\mathrm{Pb}$ come from high traffic and from industrial sources. Selenium remains in water as (selenate $\left(\mathrm{SeO}_{4}^{2-}\right)$ biselenite $\left(\mathrm{HSeO}_{3}^{-}\right)$selenite $\left(\mathrm{SeO}_{3}^{2-}\right)$, at $\mathrm{pH} 7.0$ - 9.4 (WHO Guideline (1998) 
Table 2. Toxic and trace metals in Dhaka water (rain, river and groundwater) ( $\mu \mathrm{g} / \mathrm{L})$. Legend; R: river water, G: groundwater, Ra: rainwater. Legend; R: river water (R1, R3, R5, R6, R8, R10 and R12), G: groundwater (G2, G4, G7, G9, G11, G13, G16) and Ra: rainwater (Ra14, Ra15, G16, Ra17 and Ra18).

\begin{tabular}{|c|c|c|c|c|c|c|c|c|c|c|c|c|c|c|c|c|c|c|c|c|}
\hline $\begin{array}{c}\text { Elements } \\
\mu \mathrm{g} / \mathrm{L}\end{array}$ & $\mathrm{R} 1$ & G2 & R3 & G4 & R5 & R6 & G7 & $\mathrm{R} 8$ & G9 & R10 & G11 & $\mathrm{R} 12$ & G13 & Ra14 & Ra15 & G16 & Ra17 & Ra18 & $\begin{array}{c}\text { Industrial } \\
\text { water }^{\mathrm{a}}\end{array}$ & $\begin{array}{l}\text { Ground } \\
\text { water }^{\mathrm{a}}\end{array}$ \\
\hline & 1 & 2 & 3 & 4 & 5 & 6 & 7 & 8 & 9 & 10 & 11 & 12 & 13 & 14 & 15 & 16 & 17 & 18 & & \\
\hline B & 49.58 & 37.60 & 63.17 & 35.99 & 126.82 & 45.22 & 45.96 & 134.87 & 143.93 & 138.68 & 89.97 & 116.95 & 41.25 & 90.60 & 45.75 & 26.06 & 44.70 & 140.9 & 10000 & 1000 \\
\hline $\mathrm{Cr}$ & 4.23 & 0.52 & 3.73 & 0.93 & 18.59 & 0.98 & 0.31 & 1.08 & 0.25 & 0.40 & 0.50 & 0.77 & 0.91 & 0.35 & 0.35 & 1.55 & 0.20 & 0.12 & 2000 & \\
\hline $\mathrm{Mn}$ & 3.75 & 20.46 & 3.63 & 27.78 & 31.37 & 1.30 & 110.87 & 23.84 & 130.47 & 0.52 & 71.48 & 2.03 & 1.90 & 0.58 & 5.20 & 26.63 & 2.09 & 1.76 & 10000 & \\
\hline $\mathrm{Fe}$ & 83.71 & 13.56 & 82.10 & 30.84 & 81.27 & 26.15 & 74.74 & 23.87 & 9.90 & 12.97 & 22.14 & 76.50 & 24.07 & 19.33 & 10.51 & 10.40 & 23.62 & 5.93 & 10000 & \\
\hline $\mathrm{Cu}$ & 3.58 & 1.01 & 3.53 & 1.43 & 7.59 & 2.46 & 0.97 & 2.47 & 1.91 & 1.22 & 1.21 & 3.53 & 2.71 & 2.34 & 0.92 & 32.41 & 30.61 & 28.06 & 3000 & \\
\hline $\mathrm{Zn}$ & 8.47 & 64.65 & 13.70 & 14.90 & 63.64 & 3.59 & 2.61 & 12.01 & 32.37 & 4.66 & 6.20 & 6.43 & 2.73 & 65.46 & 848.36 & 2903.55 & 536.52 & 19.62 & 2000 & \\
\hline As & 3.39 & 2.50 & 3.85 & 5.00 & 5.78 & 3.96 & 1.51 & 2.69 & 1.11 & 3.53 & 1.36 & 4.88 & 4.92 & 1.67 & 1.39 & 0.52 & 0.39 & 0.49 & 100 & 10 \\
\hline $\mathrm{Se}$ & 0.12 & 0.08 & 0.11 & 0.05 & 0.12 & 0.10 & 0.03 & 0.09 & 0.04 & 0.06 & 0.04 & 0.08 & 0.05 & 0.09 & 0.17 & 0.02 & 0.02 & 0.01 & 100 & 10 \\
\hline $\mathrm{Cd}$ & 0.02 & 0.04 & 0.02 & 0.02 & 0.04 & 0.01 & 0.00 & 0.03 & 0.05 & 0.05 & 0.28 & 0.08 & 0.01 & 0.22 & 0.12 & 0.06 & 0.03 & 0.03 & 30 & 3 \\
\hline Cs133 & 4.29 & 24.42 & 4.41 & 0.32 & 3.21 & 3.00 & 0.00 & 6.73 & 0.69 & 1.21 & 0.48 & 3.45 & 0.88 & 1.15 & 3.69 & 1.26 & 0.85 & 0.32 & & \\
\hline $\mathrm{Pb}$ & 1.76 & 1.99 & 1.17 & 2.62 & 2.70 & 1.05 & 1.12 & 0.66 & 0.89 & 0.90 & 1.20 & 2.28 & 2.49 & 2.07 & 1.31 & 5.04 & 0.58 & 0.68 & 100 & 10 \\
\hline U238 & 0.14 & 0.17 & 0.20 & 0.37 & 0.28 & 0.24 & 0.40 & 0.09 & 0.20 & 0.17 & 1.42 & 0.27 & 2.75 & 0.01 & 0.00 & 0.01 & 0.01 & 0.00 & & \\
\hline
\end{tabular}

ajapan Limit 2012.

$=0.04 \mathrm{mg} / \mathrm{L}$ ) [32]. Selenium concentration may increases at industrial areas (Stn.1 - 5) for the manufacturing operations.

\subsection{Measurements of Water Isotope to Survey the Water Sources in Catchments and Recharge of $\delta^{180}$ in Groundwater}

A plot of measured $\delta^{18} \mathrm{O}$ vs. $\delta \mathrm{D}$ identifies the mechanisms responsible for stream flow generation and can also identify the sources of solutes in contaminated systems. $\delta^{18} \mathrm{O}$ and $\delta^{2} \mathrm{H}$ follow the "meteoric water line Equation" in precipitation (rain, snow, sleet, hail, etc.):

$$
\delta 2 \mathrm{H}=8 \cdot \delta^{18} \mathrm{O}+\mathrm{d}
$$

Eq. 2

The parameter $\mathrm{d}$, is known as "deuterium excess" (d-excess) (Dansgaard, 1964), which is characterized by a marked variation globally. However, a first estimate of the global average d-excess was originally reported by Craig (1961) to be $10 \%$ [33].

The spatial distributions of $\delta^{18} \mathrm{O}$ and $\delta^{2} \mathrm{H}$ are shown in Figure 5(a) and Figure 5(b). The calculated ranges of isotopic compositions for Dhaka Water were $-3.8 \%$ to $-8.6 \%$ for $\delta^{18} \mathrm{O}$ values and $-29.4 \%$ to $-39.7 \%$ for $\delta \mathrm{D}$ values. The $\delta 180$ became depleted at the center of the city (Figure $5(\mathrm{c})$ ) as well as in some contaminated Buriganga Water and increased in ground and river water in $\mathrm{Bu}$ riganga areas (Figure 5(a), Figure 5(b)). This suggests that there may be some invasion of water from the Buriganga River. The $\delta^{18} \mathrm{O}$ increased in shallow groundwater (Saturia: $-3.61 \% \delta^{18} \mathrm{O}$ and $-28.9 \% \circ \delta \mathrm{D}$ ). Supply water from Balurpar, Gourlane, Nasirabad are belong to same sources, therefore, the $\delta \mathrm{D}$ and $\delta^{88} \mathrm{O}$ values and hexagonal diagram are similar for these 3 stations (Figure 5(d)). Although 


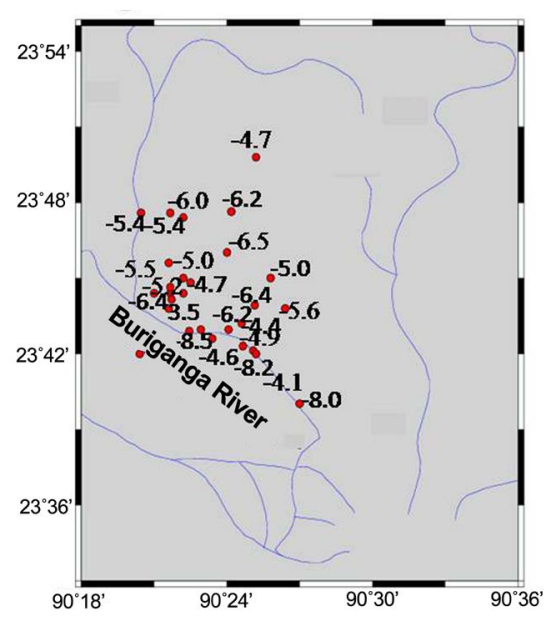

(a)

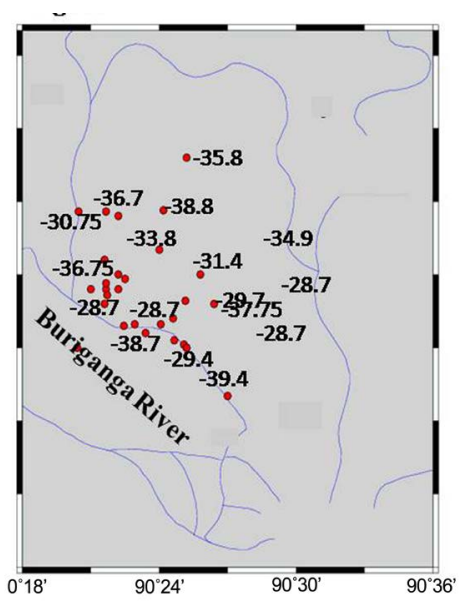

(b)

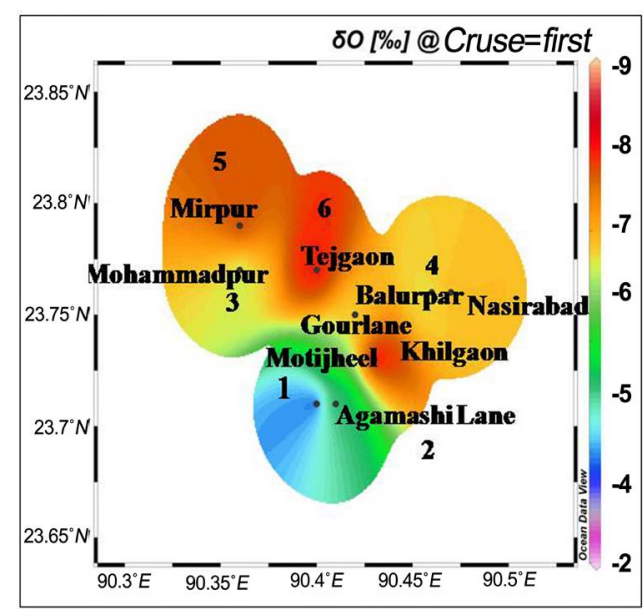

(c)

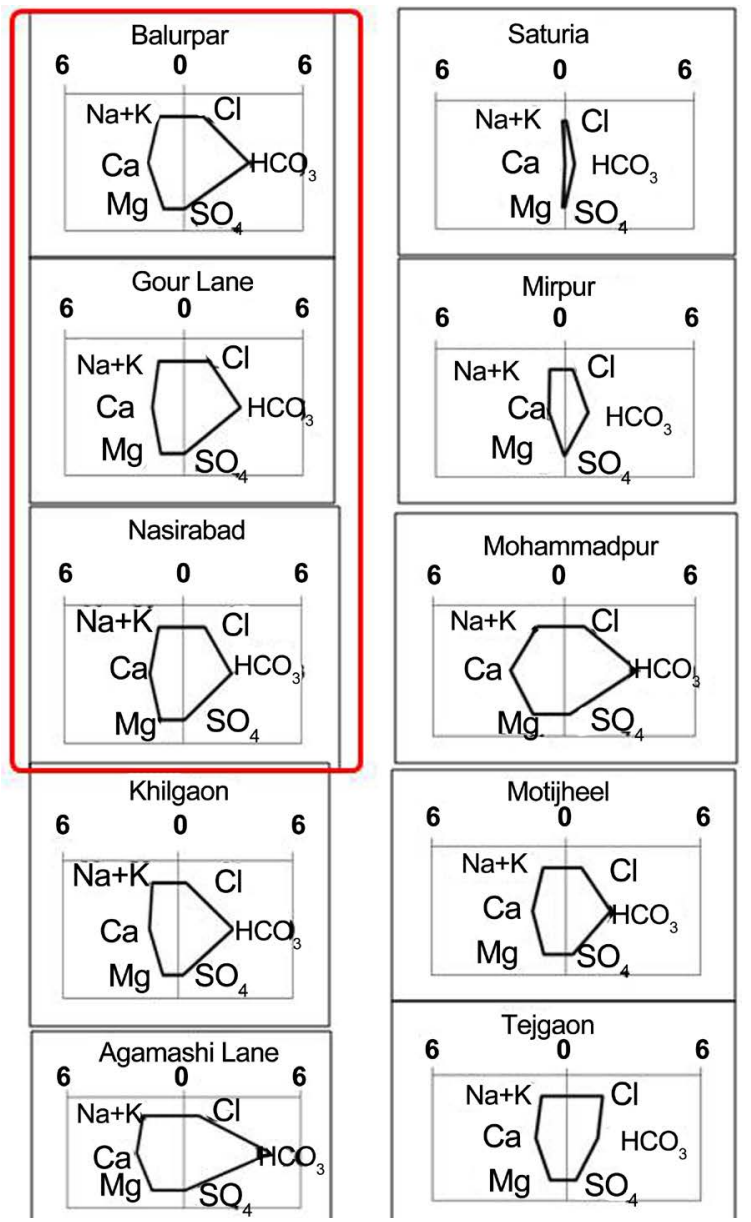

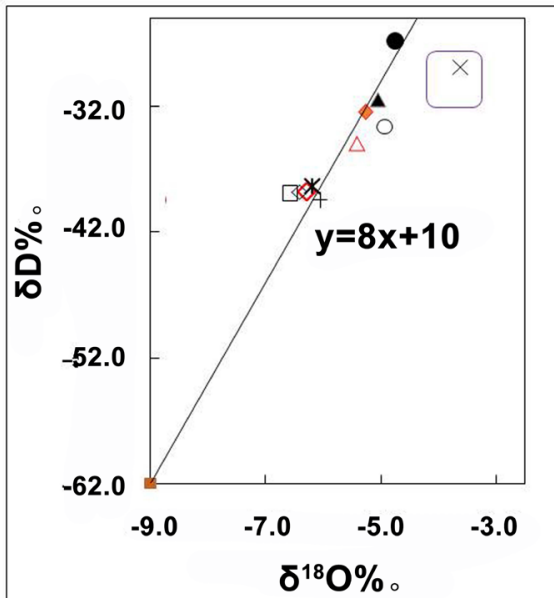

- Buriganga

$x$ Saturia

$\Delta$ Khilgaon

$\square$ Motijheel

Tejgaon

$\triangle$ Mirpur

Mohammadpur

$\diamond$ Balurpar

+ Nasirabad

* Gourlane

OAgamashilane

(d)

Figure 5. (a) (b) Similarities in $\delta 180$ and $\delta \mathrm{D}$ composition of water from Buriganga River, deep ground and shallow groundwater around the polluted Buriganga River; (c) Colored map of $\delta^{18} \mathrm{O}$ distribution in Dhaka supply water; (d) Evaluate the origin of water by using water tracer $(\delta 18 \mathrm{O})$ and hexa-diagram (Stiff Diagram).

Khilgaon is belong to the same area but the different $\delta \mathrm{D}$ and $\delta^{18} \mathrm{O}$ values and hexagonal shape revels that the supply water source is different compare to those 3 stations (Figure $5(\mathrm{~d})$ ). The $\delta \mathrm{D}$ vs $\delta^{88} \mathrm{O}$ diagram shown in Figure $5(\mathrm{~d})$ indi- 
cates that the $\delta \mathrm{D}$ and $\delta^{18} \mathrm{O}$ values lie on the LMWL.

Therefore, the magnitude of the oxygen isotope shift depends on the original O-isotope compositions of both water and rock, the mineralogy of the rock, water contaminant, the water/rock ratio and the contact duration time [34].

\section{Conclusion}

A number of geochemical dispersion patterns are obtained for major ions, trace heavy metals, isotopes ( $\delta^{18} \mathrm{O}$ and $\delta \mathrm{D}$ ) including radio isotope $\mathrm{U} 238$ in Dhaka Water. Chemical/isotopic monitoring was capable of discriminating between the effects of induced recharge from the polluted rain, Buriganga River in contaminated urban areas. The data of water tracer $\left(\delta^{18} \mathrm{O}\right.$ and $\left.\delta \mathrm{D}\right)$ indicated the water recharged from river to shallow groundwater system. Deep groundwater is not contaminated like shallow groundwater. The U238 map shows two prominent highs-both groundwaters are near the industrial areas. Maximum heavy metals (Cr, Pb, U238, Cs-133, etc.) and boron (B) show significantly higher concentrations in Buriganga River and groundwater near the leather industrial areas compared to other areas. High content of anthropogenic elements $(\mathrm{Cu}, \mathrm{Zn}, \mathrm{Pb})$ was determined in areas, dominated by commercial and high traffic (Motijheel, Mirpur) and new building construction activity (Baribadh, Matikata, Dhaka). Water analyses also reveal a correlation between toxic heavy metals loading and its watershed; it hypothesizes that heavy metals in river and groundwater are directly correlated to heavy metals loading fluxes from direct discharge of wastewater from leather industries into Buriganga River, connecting with discharge drain near the Metro Housing, West Dhanmondi, Dhaka. The data for DO (0.3 $3 \mathrm{mg} / \mathrm{L}$ ) in Buriganga River agree that the hypoxic zone is the result of the huge loads of organic content that discharge from leather industries. As organic content decomposes, oxygen is consumed in the process, resulting in low levels of oxygen in the river water. This study provided important data information for better understanding geochemical condition in urban freshwaters. Although, Dhaka (central) soil has a large special capacity for adsorbing dissolved arsenic in the Bengal Aquifer system, the geochemical cycles are controlled by nonnative materials from anthropogenic sources that alter the Dhaka Geochemical system.

\section{Acknowledgements}

We want to give very special thanks to "Environmental Clean Project, Dhaka Bangladesh" for the purpose of local data collection, sampling and for Graphic Design.

\section{References}

[1] Dhaka Water Supply and Sewerage Authority (DWASA) (2002) Management Information Report for the Month of April 2002. Dhaka.

[2] Nahar, M.S. (2002) Environmental Chemistry. Bangla Academy, Bangladesh National Publisher, 1-142.

[3] Nahar, M.S. (1999) Science and Technology Related Activities in Bangladesh. Ban- 
gladesh National Scientific and Technical Documentation Center, 1-155.

[4] Nahar, M.S. (2016) Geochemistry, from Rain Water to Groundwater and Pollution in Dhaka Water, Bangladesh. Japan Geoscience Meeting Union, Makuhari, 22-26 May 2016, AHW17-01.

[5] Nahar, M.S., Zhang, J., Ueda, A. and Fujishiro, Y. (2014) Severe Water Problem Investigation in Urban Areas of a Developing Country: The Case of Dhaka, Bangladesh. Environmental Geochemistry and Health, 36, 1079-1094. https://doi.org/10.1007/s10653-014-9616-5

[6] Werner, A.-H. and Gleeson, T. (2012) Regional Strategies for the Accelerating Global Problem of Groundwater Depletion. Nature Geoscience, 5, 853-861.

[7] Nahar, M.S. and Zhang, J. (2010) Influence of Biogeochemical Qualities of Shizuoka Water on the Degradation of PVC Shower Hose. Journal of Environmental Protection, No. 2, 204-212.

[8] Nahar, M.S. and Zhang, J. (2011) Concentration and Distribution of Organic and Inorganic Water Pollutants in Eastern Shizuoka, Japan. Toxicological and Environmental Chemistry, 93, 1946-1955. https://doi.org/10.1080/02772248.2011.610498

[9] Duval, J.S., Jones, W.J., Riggle, F.R. and Pitkin, J.A. (1990) Potassium and Thorium Maps of the Conterminous United States. US Geological Survey Open-File Report 90-338, 17 p. (Scale 1:2,500,000).

[10] Miras, Y., et al. (2015) Tracking Long-Term Human Impacts on Landscape, Vegetal Biodiversity and Water Quality in the Lake Aydat Catchment (Auvergne, France) Using Pollen, Non-Pollen Palynomorphs and Diatom Assemblages. Palaeogeography, Palaeoclimatology, Palaeoecology, 424, 76-90. https://doi.org/10.1016/j.palaeo.2015.02.016

[11] Xu, Y., Ma, C., Huo, S., Xi, B. and Qian, G. (2012) Performance Assessment of Water Quality Monitoring System and Identification of Pollution Source Using Pattern Recognition Techniques: A Case Study of Chaohu Lake. Desalination and Water Treatment, 47, 182-197. https://doi.org/10.1080/19443994.2012.696797

[12] Kanemoto, K., Moran, D. and Hertwich, E.G. (2016) Mapping the Carbon Footprint of Nations. Environmental Science \& Technology, 50, 10512-10517. https://doi.org/10.1021/acs.est.6b03227

[13] Gustavsson, N., Lampio, E., Nilsson, B., Norblad, G., Ros, F. and Salminen, R. (1994) Geochemical Maps of Finland and Sweden. Journal of Geochemical Exploration, 51, 143-160. https://doi.org/10.1016/0375-6742(94)90015-9

[14] Lisa, G., Chambers, Y.-P., Chin, G.M., Filippelli, C.B., Gardner, E.M., Herndon, D.T., Long, W., Berry Lyons, G.L., Macpherson, S.P., McElmurry, C.E., McLean, J.M., Ryan, P., Moyer, K., Carmen, A., Nezat, K., Nadya, T. and Elisabeth, W. (2016) Developing the Scientific Framework for Urban Geochemistry. Applied Geochemistry, 67, 1-20. https://doi.org/10.1016/j.apgeochem.2016.01.005

[15] Başak, B. and Alagha, O. (2010) Trace Metals Solubility in Rainwater: Evaluation of Rainwater Quality at a Watershed Area, Istanbul. Environmental Monitoring and Assessment, 167, 493-503. https://doi.org/10.1007/s10661-009-1066-7

[16] Nahar, M.S. and Zhang, J. (2013) Recovery of Trace Metal Isotopes in Seawater Samples Using Multifunctional Neem (Azadirachta indica) Biosorbent: A Comparison with Monofunctional NOBIAS-Chelate-PA1 Resin. ACS Sustainable Chemistry \& Engineering, 1, 488-495. https://doi.org/10.1021/sc3001433

[17] Ongley, E.D. (1999) Water Quality: An Emerging Global Crisis. In: Trudgill, S.T., Walling, D.E. and Webb, B.W., Eds., Water Quality: Processes and Policy, Wiley, 
London, 29-31.

[18] Filippova, L.G., Nifatov, A.P. and Lyubchanskii, E.R. (1978) Some of the LongTerm Sequelae of Giving Rats Enriched Uranium. Radiobiologiya, 18, 400-405. (In Russian)

[19] Satake, H. and Iizuka, Y. (1997) Automatic Hydrogen Isotope Measurement for Snow Samples in the Polar Regions Using a Hydrogen Isotope Exchange Method. Geoscience, 20, 128-129. (In Japanese)

[20] Ahmed, K.H., Hasan, M.K., Burgess, W.G., Dottridge, J., Ravenscroft, P. and Van Wonderen, J.J. (1999) The DupiTila Aquifer of Dhaka, Bangladesh: Hydraulic and Hydrochemical Response to Intensive Exploitation. In: Chilton, P.J., Ed., Groundwater in the Urban Environment: Selected City Profiles, AA Balkema, Rotterdam, 19-30.

[21] Burgess, W.G., Hasan, M.H., Rihani, E., Ahmed, K.M., Hoque, M.A. and Darling, W.G. (2011) Groundwater Quality Trends in the DupiTila Aquifer of Dhaka: Bangladesh Sources of Contamination Evaluated Using Modelling and Environmental Isotopes. International Journal of Water Resources Development, 3, 56-76.

[22] Lee, T.-C. (1998) Leegram: A Program for Normalized Stiff Diagrams and Quantification of Grouping Hydrochemical Data. Computers and Geosciences, 24, 523 529. https://doi.org/10.1016/S0098-3004(98)00073-9

[23] Lipfert, G., Reeve, A.S., Sidle, W.C. and Marvinney, R. (2006) Geochemical Patterns of Arsenic-Enriched Ground Water in Fractured, 12 Crystalline Bedrock, Northport, Maine, USA. Applied Geochemistry, 21, 528-545.

https://doi.org/10.1016/j.apgeochem.2005.12.001

[24] Piper, A.M. (1944) A Graphical Procedure in the Geochemical Interpretation of Water Analysis. Transactions American Geophysical Union, 25, 914-928. https://doi.org/10.1029/TR025i006p00914

[25] Babel, S. and Kurniawan, T.A. (2003) Low-Cost Adsorbents for Heavy Metals Uptake from Contaminated Water: A Review. Journal of Hazardous Materials, B97, 219-243. https://doi.org/10.1016/S0304-3894(02)00263-7

[26] Wako, T. (2012) Industrial Wastewater Management in Japan. Ministry of Environment, Japan.

[27] BGS (British Geological Survey) Arsenic Contamination of Groundwater in Bangladesh, Final Report, British Geological Survey Technical Report WC/00/19.

[28] Islam, F.S., Gault, A.G., Boothman, C., Polya, D.A., Charnock, J.M., Chatterjee, D. and Lloyd, J.R. (2004) Role of Metal-Reducing Bacteria in Arsenic Release from Bengal Delta Sediments. Nature, 430, 68-71. https://doi.org/10.1038/nature02638

[29] Bangladesh Gazette, Notification, Ministry of Environment and Forest, Government of the People's Republic of Bangladesh (1997) The Environment Conservation Rules.

[30] Cooman, K., Gajardo, M., Nieto, J., Bornhardt, C. and Vidal, G. (2003) Tannery Waste Water Characterization and Toxicity Effects on Daphnia spp. Environmental Toxicology, 18, 45-51. https://doi.org/10.1002/tox.10094

[31] Cheng, M.-C., You, C.-F., Lin, F.-J, Huang, K.-F. and Chung, C.-H. (2011) Sources of $\mathrm{Cu}, \mathrm{Zn}, \mathrm{Cd}$ and $\mathrm{Pb}$ in Rainwater at a Subtropical Islet Offshore Northern Taiwan. Atmospheric Environment, 45, 1919-1928. https://doi.org/10.1016/j.atmosenv.2011.01.034

[32] World Health Organization (1998) Guidelines for Drinking-Water Quality: Second Addendum. Vol. 1: Recommendations. 2nd Edition, Geneva, 3-12, 34.

[33] Craig, H. (1961) Isotopic Variations in Meteoric Waters. Science, 133, 1702-1703. 
https://doi.org/10.1126/science.133.3465.1702

[34] Hoefs, J. (2004) Stable Isotope Geochemistry. Springer, Berlin, 1-244. https://doi.org/10.1007/978-3-662-05406-2

Submit or recommend next manuscript to SCIRP and we will provide best service for you:

Accepting pre-submission inquiries through Email, Facebook, LinkedIn, Twitter, etc. A wide selection of journals (inclusive of 9 subjects, more than 200 journals)

Providing 24-hour high-quality service

User-friendly online submission system

Fair and swift peer-review system

Efficient typesetting and proofreading procedure

Display of the result of downloads and visits, as well as the number of cited articles Maximum dissemination of your research work

Submit your manuscript at: http://papersubmission.scirp.org/

Or contact gep@scirp.org 